\title{
Household Behavior and Response to the Participative Institutional Model for the Program of Handling Drainage of Productive Cows
}

\author{
Ardi Novra* and Bagus Pramusintho \\ Faculty of Animal Husbandry, Jambi University, Jambi, 36361, Indonesia
}

Article history

Submitted: 11 April 2019

Accepted: 25 October 2019

* Corresponding author:

Telp. +6282180037393

E-mail: ardinovra@unja.ac.id

\begin{abstract}
The research survey aimed to observe the households behavior and response to the participatory institution model of the preventing of the productive cows exploitation. The sample technique to select of the domestic cattle farmer (DCF) as the unit of analysis using the multiple stages cluster sampling and then sample allocation was equal for three districts. Structural equation model consisted of 5 behavior equations drawn up from the 5 endogenous and 13 exogenous variables. The research results showed that the rate of release of productive cows about 19.23 percent. The institutional model to handling of the drain at least productive cows have four major components, were members (DCFs), the management, micro-finance institutions (MFIs) and buffer-stock. The household motivation to develop the business scale and maintain the productive heifer shaped by land ownership and livestock scale expected factors. Then both types of motivation were not significantly associated with DCF's motivation to engage in institutional, as the more dominant individual as shaped by the farmer age. The other hand, the confidence level of participatory institutional effectiveness significantly shaped by the perception of institutional and potential release of productive heifer compared the potential release of motivation factors and correlated positively with the economic conditions.
\end{abstract}

Keywords: Heifer, Institutional, Participative, Productive, Responsive

\section{Introduction}

The Beef Self-Sufficiency Program (PSDS/Program Swasembada Daging Sapi) 2014 is grouped into five, namely the supply of local cattle/beef, increased productivity and reproducibility of local cattle, prevention of slaughtering productive cows, provision of breeding cattle, and revitalization of livestock/beef distribution/marketing rules. The cause of the rising import trend so far is thought to be due to the difficulty of domestic fattening industry players in obtaining feeder cows related to the low performance of household-scale livestock farming. This condition exacerbated by the occurrence of slaughter rates of productive cows that are still high, whereas productive cows can be used as breeding cattle (Sudrajad et al., 2011). Productive cows are cows that have given birth less than 5 (five) times, or are under 8 (eight) years of age, or cows that based on reproductive examinations are declared to have normal reproductive organs and function optimally as a mother cow and are free from infectious animal diseases (Directorate General of Animal Health and Husbandry, 2011).

Livestock Office of Jambi Province (2007) stated the obstacles to achieving the target population, production, productivity, and reproducibility of cattle at the national level are low pregnancy/birth rates and high rates of slaughtering productive cows/(pregnant). Beef self-sufficiency is projected to only be achieved in 2015 according to Harmini et al. (2011), if the government implemented a policy of reducing the slaughter of productive local cows and increasing the cross-breeding program of local cows with Artificial Insemination (IB/Inseminasi Buatan). The number of calves born per year is an average of 1.7 million head of cattle, while the need for beef cattle every year is 2.1 million and now the beef cattle population is 10.5 million-11 million head (Soedjana, 2009).

Based on the monitoring of the Directorate General of Animal Health and Husbandry in 2012, around $40 \%$ of the total number of slaughtered animals were female animals, of which around $25 \%$ were productive cows or about $10 \%$ of total slaughtering animals, the remaining $5 \%$ were advanced livestock and $10 \%$ old cattle (reject). The national slaughter rate of cattle is 1.7 million/head/year. If it is assumed a $10 \%$ slaughter rate for productive cows, the number of slaughtered cows is 170 thousand heads each year. Some of the results of research on slaughter rates for productive cows so far are quite alarming, as in Tulung Agung District, of the 309 
cows that slaughtered, there is $23.69 \%$ or around 50 cows are productive.

The results of research on two slaughterhouses in Bali showed that $99 \%$ of cows slaughtered in Pesanggrahan slaughterhouses were classified as productive cows, while Mambal slaughterhouses were lower at $67.49 \%$ (Suardana et al., 2013). In the Kendari slaughterhouse, the majority of cattle slaughtered were Bali $(97.7 \%)$, $98.5 \%$ of them were cows consisting of productive cows (aged $1.5-4.0$ years) by $84.7 \%$ and positive pregnant 4, 9\% (Hafid and Syam, 2001). Observations on the two slaughterhouses, namely Singosari and Gadang slaughtered, proportions of productive cows cuts respectively reached 15.10 percent and 26.00 percent (Soejosopoetro, 2011).

Control of Productive Cow

(PBP/Pengendalian Sapi Betina Produktif) is one of the activities in supporting the achievement of the 2014 Beef/Buffalo Self-Sufficiency Program (PSDS/K - Program Swasembada Daging Sapi/Kerbau) in a sustainable manner (management guidelines of Control of Productive Cow/PBP, 2013). This activity has been carried out since 2010 through Social Assistance funds (Bansos/Bantuan Sosial) and continued in the 2011 fiscal year with Incentives and Rescue Activities for Cattle/Buffalo Buffers (IPBP/ Penyelamatan Sapi/Kerbau Betina Produktif). The objective of selecting productive cows, according to Directorate General of Animal Health and Husbandry, (2011), is to capture or save productive cows from slaughtering in slaughterhouses, provide productive cows for the community to increase birth rates, and strengthen group capital by utilizing productive cow nets. Another step is through the supervision of live cattle trade between provinces but not yet supported by Local Government Regulation (PERDA/Peraturan Daerah) and Joint Directive of Local Leaders (SKB Kepala Daerah). The dilemmatic condition faced by the slaughterhouse is because the tightening of rules will cause increasingly deep cuts outside the slaughterhouse or other districts/cities that do not strictly enforce the prohibition of cutting young and productive cows (AIAT of Central Java and Livestock Office of Central Java, 2005).

Efforts to minimize slaughtering productive cows to a level of $2 \%$ have an impact equivalent to efforts to reduce parent mortality by $10 \%$ (Mahbubi, 2014). The program, to prevent the drainage of productive cows, is more effective if it is carried out directly at the "main door" for the release of breeding cattle, namely households. Livestock release is a household production decision, and according to Chilonda and Van Huylenbroeck (2001), this behavior influenced by variables related to livestock farmers and business characteristics, economic, institutional, and biophysical factors. Other factors that are also closely related to behavior and decision making are household characteristics, namely the number of family members, and social and cultural factors such as social capital, cultural values (Squires, 2003).

Prevention will be more effective if done early through collective action, or jointly which requires participatory behavior. Collective action has an influence on individuals and society at large, which will have an impact on the actions of the individual itself, and if each individual ultimately decides on the same action, then it will affect the community (Satriawan and Oktavianti, 2012). Generally, in rural communities, collective action is carried out through formal or informal organizations or groups. Each group member must have a strong motivation to cooperate as a basis for collective action, be trustworthy, honest, and respect the opinions of others (Komarudin et al., 2008). The main elements of the institution are the actors of the organization (a player of the game) and the rules about the relationship among them in the organization (law of enforcement). It means that the institution contains a broader understanding than just the organization because it also includes rules that are agreed upon by internal actors and other related parties.

Preventing the continued depletion of productive cows, in 2009 through the Research and Development Agency of Jambi Province, a participatory institutional model developed. Implementation of the model requires a study to be effective in its implementation, especially related to the behavior of the release of productive cows and household responses to the participatory institutional model. Based on this, a study was conducted to identify the behavior of cattle raiser households in the release of productive cows, which expected taken into consideration in preparing the strategic plan for implementing the participatory institutional model.

\section{Materials and Methods}

\section{Time and location of research}

This research was conducted in Jambi Province for 10 months with 3 (three) districts as survey target areas representing 3 (three) geographical regions, namely Sarolangun Regency (western region drawing highland communities), Muaro Jambi (central region describing the plain communities medium), and Tanjung Jabung Timur (eastern region representing lowland or coastal communities). The three geographical areas have different characteristics, both from aspects of layout, natural resources, and social culture that will influence farming behavior patterns and responses to development programs.

\section{Data types and sources}

The kind of data in this study consisted of primary data sourced from the results of direct observations of breeder households $(\mathrm{BH})$ using questionnaires, as well as secondary data sourced from various related institutions. The participatory institutional model that used as the basis for identifying household behaviors and 
responses was the result of Novra and Depison's (2009) research on the design of participatory institutional models for handling productive cows. The main component of participatory institutions was beef cattle breeders, with the support of other parties both directly and indirectly with the links, as shown in Figure 1.

The participatory institutional model shows that the selection of livestock in a participatory manner in groups done by empowering the tasks and functions of each party. Governance in a participatory institutional model includes the flow of cattle and funds in groups but also does not rule out the possibility of reaching out to nongroup breeders in the surrounding rural areas concerned. Cattle released by the household for whatever reason, both for sale and slaughter purposes, must be done through groups or permission from the group. Sales of ready-forslaughtered cattle such as bulls from fattening (adult) and cows that rejected or having reproductive disorders can be directly sold and sufficiently through group notification. Conversely, productive livestock such as steer (prospective parent), heifer, and productive age should be prevented from escaping (netting).

\section{Sampling technique}

The number of beef cattle ranchers' households that became the unit of analysis in the study was $150 \mathrm{BH}$. They were selected through a multi-stage random sampling technique (Multistage Cluster Random Sampling) with an equal allocation for each region (50 BH) (Figure 2).

This research uses stock taking study data collection approach, especially associated to best practices, which is the determining factor for achieving success stories that had been done by groups despite being not well organized. The public feasibility test developed a structural equation model to determine the determinants of the release of productive cows and level of Breeder Household confidence in the effectiveness of the participatory model consisting of 5 (five) equations with 5 endogenous variables (MOTS, MPBT, MOTP, PPSB and TKYN) and 13 exogenous variables (AKUK, SKUT, LPRO, CURT, PJBP, EXPL, LBET, SKUE, UMUR, PEND, ROLE, INCO and PKLP) using the following formulation:

MOTS $=\alpha_{1.0}+\beta_{1.1}$ AKUK $+\beta_{1.2}$ SKUT + $\beta_{1.3}$ LPRO $+\beta_{1.4}$ CURT $+e_{1}$

Expected parameter: $\beta_{1.1}>0$ and $\beta_{1.2}, \beta_{1.3}, \beta_{1.4}<0$

MPBT $=\alpha_{2.0}+\beta_{2.1} P J B P+\beta_{2.2} E X P L+$ $\beta_{2.3}$ LBET $+\beta_{2.4}$ SKUE $+e_{2}$

Expected parameter: $\beta_{2.1}, \beta_{2.2}, \beta_{2.3}, \beta_{2.4}>0$

MOTP $=\alpha_{3.0}+\beta_{1.1}$ MOTS $+\beta_{3.2}$ MPBT + $\beta_{3.3}$ UMUR $+\beta_{3.4}$ PEND $+\mathrm{e}_{3}$

Expected parameter: $\beta_{3.1}, \beta_{3.2}, \beta_{3.3}, \beta_{3.4}>0$
PPSB $=\alpha_{4.0}+\beta_{4.1}$ ROLE $+\beta_{4.2} I \mathrm{NCO}+\mathrm{e}_{4}$

Expected parameter: $\beta_{4.1}>0$ and $\beta_{4.2}<0$

TKYN $=\alpha_{5.0}+\beta_{5.1}$ MOTP $+\beta_{5.2}$ PPSB +

$\beta_{5.3} \mathrm{PKLP}+\mathrm{e}_{5}$ (5).

Expected parameter: $\beta_{5.1}, \beta_{1.2}, \beta_{5.3}>0$

Information:

MOTS = Motivation to enhance the scale of a cattle business (percent)

MPBT = Motivation to maintain productive female cattle (percent)

MOTP = Motivation to get involved in participatory institutions (percent)

PPSB = Potential to release productive female cattle (percent)

TKYN = Level of confidence in the participatory model offered (percent).

Determination of the motivation value, potential for release and level of confidence using the formulation and indicators as follows

$$
\mathrm{V}_{\mathrm{i}}(\%)=\frac{\mathrm{NS}-\mathrm{NA}}{\mathrm{NS}} \times 100 \%
$$

Where $\mathrm{V}$ (the value obtained), NS (maximum value or number of categories) and NA (the value of the final answer obtained from the results of the interview). The basic reference assessment approach (PAK) is used for grouping each endogenous variable, which is very low $(<40$ percent), low (40 - 50 percent), moderate $(50-60$ percent), high (60 - 70 percent) and very high (> 80 percent).
AKUK = Number of $\mathrm{BH}$ members classified as working age (person)
SKUT = Scale of beef cattle business (UT)
LPRO = Total area of land assets claimed by the $\mathrm{BH}(\mathrm{Ha})$
CURT = Branches of farming and non-farming dealt by $\mathrm{BH}$ (kind)
PJBP = Proportion of cow in the $\mathrm{BH}$ business (percent)
EXPL = Experience of releasing productive cow (times)
LBET = Length of breeding (years)
SKUE = Expected scale of beef cattle business (head)
UMUR = Age of beef cattle farmers (years)
PEND = Breeders Education
ROLE = Role of livestock business in the family economy
INCO = BH income (Million IDR)
PKLP = Perception about participatory institutions (percent).

Data processing and tabulation(2)sing MSexcel program and later performed statistical analysis of structural equation models with the 2SLS (two stage least squares) estimation technique using SAS/ETS 9.12. 


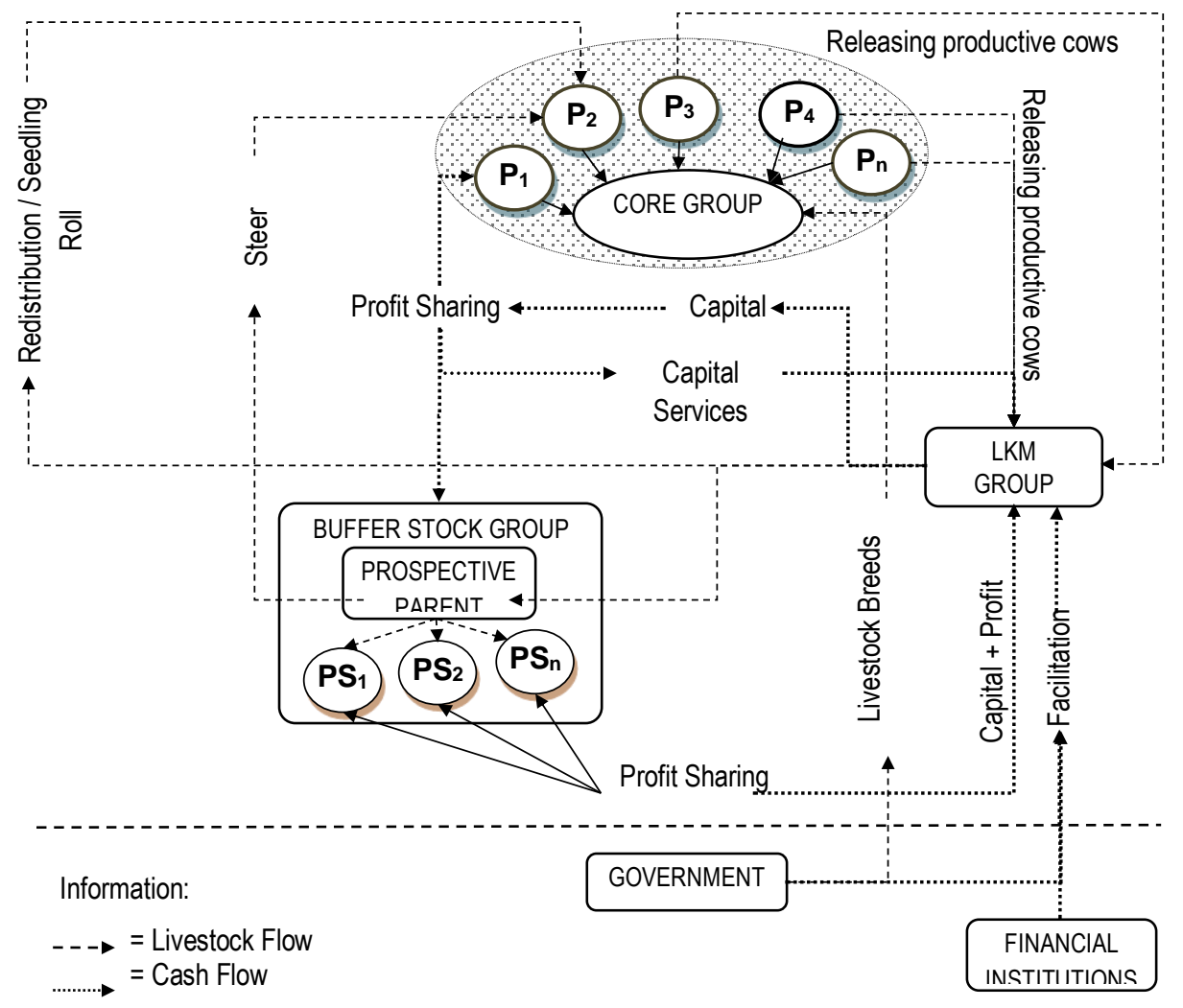

Source: Novra and Depison, 2009

Figure 1. Institutional Model Framework Tested.

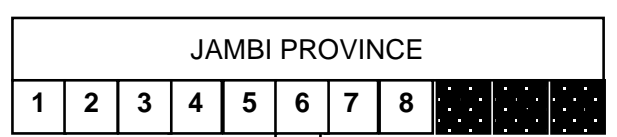

STAGE 1

STAGE 2

STAGE 3

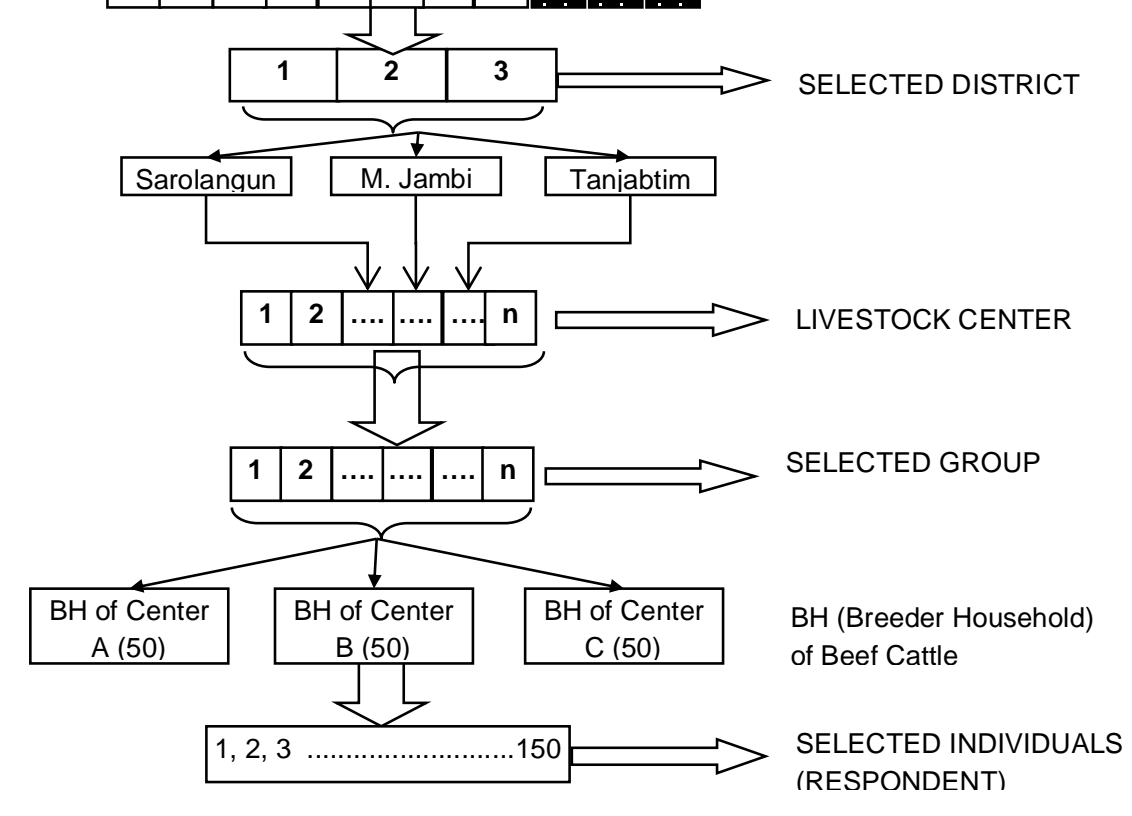

STAGE 4

Figure 2. Sampling Framework. 


\section{Results and Discussion}

\section{Release of cattle by households}

Release of cattle by households can be sold to other parties or cut to meet the consumption needs of certain activities such as weddings and other activities that require large amounts of beef. Release of cattle by household is not always done throughout the year but within a certain time period by considering several things such as the age of the cattle, the scale of the existing cattle business and because of certain needs. Based on the previous facts, the observation of the release of cattle is carried out for 5 (five) years with the aim to better identify the behavior or process of release of livestock by each household as presented in Table 1.

Release of cattle by breeder households $(\mathrm{BH})$ is still relatively low with the aim of releasing it to be sold to other parties. Over a 5-years period, there were $12.67 \%$ of households that had released their cattle with the highest proportion in the Sarolangun Regency. The average number of cattle released during the period reached 0.17 head/ BH with the largest composition of cow but the household in the Batanghari Regency. This comparison between regions is due to the role of $\mathrm{BH}$ in Muaro Jambi District, which is a sub-urban area, as a supplier of beef cattle. On the other hand, based on age groups, then the release of cattle is generally grown up cattle and vice versa, $\mathrm{BH}$ not once has releases calves. There are some cattle which are released from the household are classified as productive cows (aged $2-8$ years) with an average proportion of $19.23 \%$ or 0.03 out of 0.17 head of cattle released by $\mathrm{BH}$. The proportion of this release is relatively large, especially in 2 regions, namely Sarolangun and East Tanjab with the proportion reaching $25 \%$ or 1 of 4 heads released as productive cow. The release of productive cow is related to the motivation of the $\mathrm{BH}$ to retain livestock and the potential release of productive cow themselves.

\section{Indicator of participatory institutional feasibility \\ The potential for institutional development} in the Beef Cattle BH group is related to the rational thinking patterns that develop in the lives and efforts of beef cattle farms. Some variables such as perception and motivation and level of confidence can be used as indicators of whether the institutional form offered is acceptable to households. The accumulation of perceptions and motivation to participate as well as the level of confidence in operational effectiveness is an important factor to determine the potential for participatory institutional development in handling productive cow as presented in Table 2 in general. The motivation of $\mathrm{BH}$ to be actively involved in the institutional system offered is moderate but the perceptions and the level of confidence is considerably high.

Comparison between regions does not show a positive correlation among the three indicators and even the higher the motivation and perception of the institutions offered, the lower the level of confidence in the effectiveness of the institution to be developed. This is especially evident from the correlation between the value of perception and motivation with the level of belief in $\mathrm{BH}$ in the Sarolangun Regency. This phenomenon becomes quite interesting, it turns out that better knowledge causes even a high level of doubt

Table 1. The purpose and number of cattle based on age released by the breeder household

\begin{tabular}{|c|c|c|c|c|c|}
\hline \multirow{2}{*}{ No } & \multirow{2}{*}{ Elucidation } & \multicolumn{3}{|c|}{ Regency } & \multirow{2}{*}{ Average } \\
\hline & & SR & MJ & TJT & \\
\hline \multirow{3}{*}{ A } & The release of livestock by the household & 10 & 800 & م0 & 897 \\
\hline & b. Slaughter (percent) & 8.00 & 4.00 & 0.00 & 4.00 \\
\hline & Total & 18.00 & 12.00 & 8.00 & 12.67 \\
\hline \multirow{2}{*}{ B } & Livestock Released Gender & & & & \\
\hline & b. Cow (head) & 0.08 & 0.06 & 0.16 & 0.10 \\
\hline \multirow{4}{*}{ C } & Productive Cow Group & & & & \\
\hline & a. Average of the Cow Released (head) & 0.16 & 0.20 & 0.16 & 0.17 \\
\hline & b. Productive Cow Group (head) & 0.04 & 0.02 & 0.04 & 0.03 \\
\hline & c. Drainage Level (percent) & 25.00 & 10.00 & 25.00 & 19.23 \\
\hline
\end{tabular}

Note: $\mathrm{SR}$ = Sarolangun, MJ = Muaro Jambi and TJT = Tanjung Jabung Timur

Source: Processed Primary Data, 2012.

Table 2. Indicator values for potential participatory institutional development programs for handling productive cows (percent)

\begin{tabular}{|c|c|c|c|c|c|}
\hline \multirow[b]{2}{*}{ No } & \multirow{2}{*}{ Institutional Development Indicators } & \multicolumn{3}{|c|}{ Regency } & \multirow{2}{*}{ Average } \\
\hline & & SR & MJ & TJT & \\
\hline 1 & Motivation for Participation & 54.45 & 48.27 & 52.82 & 51.85 \\
\hline & Tuotivation tor rartieipation & Moderate & Low & Moderate & Moderate \\
\hline 2 & Institutional Perception & $\begin{array}{c}53.38 \\
\text { Moderate }\end{array}$ & $\begin{array}{l}65.50 \\
\text { High }\end{array}$ & $\begin{array}{c}88.50 \\
\text { Very High }\end{array}$ & $\begin{array}{l}69.13 \\
\text { High }\end{array}$ \\
\hline 3 & Confidence level & $\begin{array}{c}45.75 \\
\text { Low }\end{array}$ & $\begin{array}{c}55.50 \\
\text { Moderate }\end{array}$ & $\begin{array}{c}87.75 \\
\text { Very High }\end{array}$ & $\begin{array}{l}63.00 \\
\text { High }\end{array}$ \\
\hline
\end{tabular}

Note: SR = Sarolangun, MJ = Muaro Jambi dan TJT = Tanjung Jabung Timur

Source: Processed Primary Data, 2012 
about institutional effectiveness so that $\mathrm{BH}$ notice their uncertainty about the program. The distribution of $\mathrm{BH}$ perceptions of institutions offered, motivation for participation and level of confidence as indicators of the potential for participatory institutions in each region (Table 3).

The distribution of positive perceptions of the participatory institutions offered is relatively more evenly distributed in all regions with a high majority, while the motivation for participation is more evenly distributed in the Muaro Jambi Regency but in general is moderate and high. On the other hand, the level of confidence in the operation of participatory institutions varies more between regions but in general is classified as very high.

\section{Motivation and perception of $\mathrm{BH}$ towards participatory institutions}

The design of a participatory institutional model including in handling the drainage of productive cows is related to the behavior patterns of breeder households $(\mathrm{BH})$ in the release of productive cows. The behavior of $\mathrm{BH}$ is associated to efforts to develop alternative solutions in a participatory institutional model and in the end can be used as a reference in determining the rules of the game and components in the institutional model that will be developed. In general, the correlation between the behaviors of $\mathrm{BH}$ with the potential for institutional development is presented in Figure 3.

The motivating factor for the participation of
$\mathrm{BH}$ in the participatory institutions offered The motivation of $\mathrm{BH}$ to participate consciously involved or participate in participatory institutional models formed due to internal factors that exist directly and indirectly in the household itself. The motivation of participation is indirectly appeared from the motivation of $\mathrm{BH}$ in the livestock business and maintaining productive cow, which is formed by the internal environment in the household. Motivation to evolve cattle business (MOTS) to a certain scale is created by ownership of assets and resources owned by households and used as a source of household economics, including potential human resource assets as labor (AKUK), ownership of farmland (LPRO) and livestock businesses that have been owned so far (SKUT) as well as economic business branches that are a source of household income (CURT) as presented in Table 4.

Land asset ownership is the main factor that most significantly determines household motivation to develop a beef cattle business scale. The relationship between asset ownership and motivation for business development reversed, where an increase in the area of land ownership will reduce the motivation of $\mathrm{BH}$ to increase the

Table 3. Classification of $\mathrm{BH}$ based on indicator value potential for participatory institutional development

\begin{tabular}{|c|c|c|c|c|c|}
\hline \multirow{2}{*}{ No } & \multirow{2}{*}{ Institutional Development Indicators } & \multicolumn{3}{|c|}{ Regency } & \multirow{2}{*}{ Average } \\
\hline & & SR & MJ & TJT & \\
\hline \multirow[t]{6}{*}{1} & Institutional Perception & & & & \\
\hline & a. Very High & - & 38.00 & 12.00 & 16.67 \\
\hline & b. High & 18.00 & 34.00 & 48.00 & 33.33 \\
\hline & c. Moderate & 22.00 & 10.00 & 18.00 & 16.67 \\
\hline & d. Low & 24.00 & 8.00 & - & 10.67 \\
\hline & e. Very Low & 36.00 & 10.00 & 22.00 & 22.67 \\
\hline \multirow[t]{6}{*}{2} & Motivation for Participation & & & & \\
\hline & a. Very High & 4.00 & 18.00 & 34.00 & 18.67 \\
\hline & b. High & 50.00 & 18.00 & - & 22.67 \\
\hline & c. Moderate & 34.00 & 34.00 & - & 22.67 \\
\hline & d. Low & 12.00 & 14.00 & 22.00 & 16.00 \\
\hline & e. Very Low & - & 16.00 & 44.00 & 20.00 \\
\hline \multirow[t]{6}{*}{3} & Confidence Level & & & & \\
\hline & a. Very High & 8.00 & 84.00 & 80.00 & 57.33 \\
\hline & b. High & 44.00 & 16.00 & 18.00 & 26.00 \\
\hline & c. Moderate & 4.00 & - & 2.00 & 2.00 \\
\hline & d. Low & 40.00 & - & - & 13.33 \\
\hline & e. Very Low & 4.00 & - & - & 1.33 \\
\hline
\end{tabular}

Note: SR = Sarolangun, MJ = Muaro Jambi and TJT = Tanjung Jabung Timur

Source: Processed Primary Data, 2012.

Table 4. The estimation results of the motivating factors for the development of beef cattle business development

\begin{tabular}{clrr}
\hline \hline No. & \multicolumn{1}{c}{ Variable } & Coefficient & P-Value \\
\hline 1. & A Constant & 40.843171 & 0.0001 \\
2. & Control of land assets (LPRO) & -1.3369 & 0.0017 \\
3. & Family workforce (AKUK) & -0.7645 & 0.2581 \\
4. & Livestock business scale (SKUT) & -1.1949 & 0.3921 \\
5. & Household business branch (CURT) & 0.3799 \\
\hline \multicolumn{2}{l}{ Information: Bolding and italics indicate a significant level of 80\% confidence (P < 0.2) }
\end{tabular}




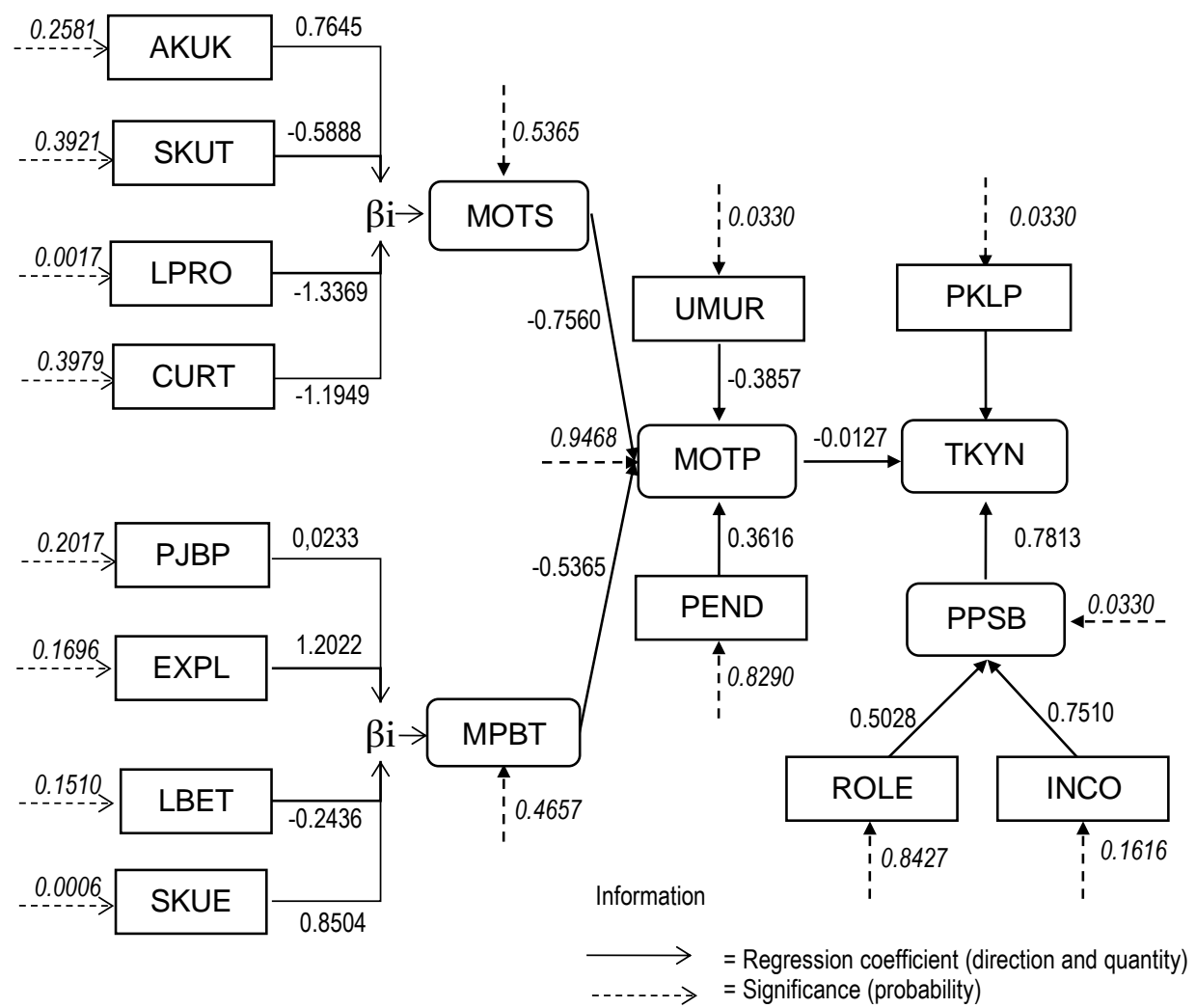

Figure 3. Summary of Estimated Results of BH Behavior and Participatory Institutions.

scale of the beef cattle business. The limitation in resources to run cattle business is a dominant consideration so that the $\mathrm{BH}$ that already has a relatively large scale cattle business will reduce its motivation to increase business scale. The same thing also indicated by variations in sources of household businesses, where the more numerous amount of time devoted causes the free time to care for cattle decreases so that the motivation to enlarge the scale of business also decreases. Conversely, the larger the availability of labor as indicated by the number of household members classified as working age (15 - 60 years), the bigger the desire or motivation to enlarge the scale of the cattle business.

Productive cow recognized by the $\mathrm{BH}$ as a crucial part that needs to be maintained to enlarge the business scale of beef cattle (Table 5). The motivation of $\mathrm{BH}$ to maintain productive cow is formed from the factors of experience and orientation of the beef cattle business that they have been trying. The most significant factor in creating the household motivation to maintain productive cow is the target or expectation of the scale of livestock business that will be achieved (SKUE) by $\mathrm{BH}$. The direction of the positive relationship indicates that for households that wants the measure of the cattle business to increase to a particular scale or expected, then maintaining productive cow is the foremost choice. This behavior is also indicated by looking at the relationship between the sex structure of cattle that kept, where the more elevated the proportion of productive cows that are owned by households (RPJP), the stronger the desire to maintain these productive cows. It means that $\mathrm{BH}$ discharges productive cow is the last choice of cattle that will be released if there is a sale or business scale adjustment.

The release of productive cows can disrupt efforts to accelerate the development of scale and felt by the $\mathrm{BH}$, who have released productive female cows. This indication can be seen from the direct relationship between experiences in the release of productive cows (EXPL) with the motivation to maintain productive cows. $\mathrm{BH}$ realizes that productive cows are one of the primary factors, and their existence needs to be maintained because it can slow down efforts to increase business scale as expected. The release of productive cows will only be done if the BHs want to rationalize the business, especially for $\mathrm{BHs}$, who have experience raising cattle (LBET). In general, long-term $\mathrm{BH}$ has a more comprehensive business scale so that the release of productive cow has become part of business management, and this factor is thought to be the cause of the unrelated relationship between the length of breeding and motivation to maintain productive cows.

The $\mathrm{BH}$ 's decision to release productive cows is related to perceptions about the function of them in the household economy. Releasing productive female cows disrupts, and if the 
problem is significant, it will be more difficult for households to make decisions to release productive cows. It causes the household group to agree, and then the potential release of productive cows will be higher, as in Table 6 .

Household income has a more significant effect than the economic role of cattle in the household economy on the potential release of productive cows. About $83.76 \%$ of the potential discharge of productive cows is determined by household income, while around $16.24 \%$ influenced by the role of cattle in the household economy. It means that the risk of releasing productive cows will be more numerous in highincome households. The same thing happens to $\mathrm{BH}$, who has a high dependency on beef cattle business, because of the significant role of livestock businesses in the household economy. This anomalous state can be illustrated by the real conditions that have occurred in some extransmigration areas in Jambi Province. In the early days of transmigration with the situation of the plantation business area that had not produced yet, cattle rising relied upon as a source of additional income. However, when plantation crops (rubber and oil palm) reached the age of productive plants and a boom in prices (the 1997 economic crisis), they began to reduce cattle ownership (selling). The focus of the labor outlay for the management (harvesting) of oil palm caused a scarcity of time availability and attention of family kindergartens for raising cattle. On the other hand, monoculture farming behavior arose because it relied only on the results of rubber or oil palm plantations. It is a phenomenon that needs to find alternative solutions to problemsolving, and one of them is by strengthening the linkages between commodities (gardens and livestock) through the development of integration models with a touch of connecting technology, namely the use of waste.

\section{Motivation and perception of $\mathrm{BH}$ towards the participatory institutional models offered}

In general, motivation to enlarge business scale is closely related to technical factors such as the availability of resources in the family, especially labor, to manage livestock businesses. On the other hand, the motivation to maintain productive cows is more related to perceptions from the household, especially orientation and experience in raising beef cattle. These two motivations together will form knowledge and perceptions of efforts to handling of the drainage of productive cows, which are the determining factors for the emergence of motivation to participate in the participatory institutions offered. Determinants of social feasibility symbols for the participatory institutional models offered presented in Table 7.

The motivation of $\mathrm{BH}$ to participate in a participatory institutional model is significantly determined by age and motivation to develop a business, but these two variables have different directions from the motivation of institutional participation (MOTP). Motivation to develop business has an unrelated relationship to participation motivation (MOTP), where the increase in business motivation is not followed in the same direction as participation motivation in the participatory institutional model offered. Concern about the effectiveness of the institutional development program offered is thought to be one of the causes so that the $\mathrm{BH}$

Table 5. The estimation results of motivating factors to maintain productive cow

\begin{tabular}{clrr}
\hline \hline No. & \multicolumn{1}{c}{ Variable } & Coefficient & P-Value \\
\hline 1. & A constant & 46.9754 & 0.0001 \\
2. & Expected business scale (SKUE) & 0.8504 & $\mathbf{0 . 0 0 0 6}$ \\
3. & The length of breeding (LBET) & -0.2436 & $\mathbf{0 . 1 5 1 0}$ \\
4. & Release experience (EXPL) & 1.2022 & $\mathbf{0 . 1 6 9 6}$ \\
5. & The proportion of productive cow (PJBP) & 0.0233 & 0.2017 \\
\hline
\end{tabular}

Information: Number "Bold": Significant level of $80 \%$ confidence (P value $<0.2$ ).

Table 6. The estimation results of factors that influence the potential release of productive cows

\begin{tabular}{clrr}
\hline \hline No. & Variable & Coefficient & P-Value \\
\hline 1. & A Constant & 27.9626 & 0.0001 \\
2. & Income of BH (INCO) & 0.7510 & 0.1616 \\
3. & The role of livestock economics in BH (ROLE) & 0.5028 & 0.8427 \\
\hline Information: Number "Bold": Significant level of $80 \%$ confidence (P value $<0.2)$ & &
\end{tabular}

Table 7. The estimation results of factors forming the social feasibility indicators of participatory institutional models

\begin{tabular}{|c|c|c|c|}
\hline No. & Variable & Coefficient & P-Value \\
\hline A. & The Motivation for Participation (MOTP) & & \\
\hline 1. & A constant & 120.2234 & 0.0124 \\
\hline 2. & Motivation to develop livestock business (MOTS) & -0.7560 & 0.0302 \\
\hline 3. & Age of household head (AGE) & -0.3847 & 0.0330 \\
\hline 4. & Motivation to maintain productive cows(MPBT) & -0.5385 & 0.4657 \\
\hline 5. & Educational group (PEND) & 0.3616 & 0.8290 \\
\hline B. & Perception of participatory institutional effectiveness (TYKN) & & \\
\hline 1. & A constant & -53.6865 & 0.0017 \\
\hline 2. & Perceptions about institutions (PKLP) & 1.3383 & 0.0001 \\
\hline 3. & Potential for release of productive cows (PPSB) & 0.7813 & 0.0214 \\
\hline 4 & The Motivation for Participation (MOTP) & -0.0127 & 0.9486 \\
\hline
\end{tabular}

Information: Number "Bold": Significant level of $80 \%$ confidence (P value $<0.2)$. 
group with high business motivation is more confident to manage themselves without having to be done in groups. Less experience in informal organizations such as livestock farmer groups and ineffectiveness makes them less willing to participate in a relatively new institutional model for them.

On the other hand, the opposite (negative) relationship between age and participation motivation indicates that younger household heads have higher participation motivation compared to older age groups. It means that the younger the head of the household, the more numerous the desire to participate in the institutions offered. High motivation in the young population is something natural because there is a great desire to try an innovation in an institutional model that they think can be hope in solving the problems they face so far. Other variables, such as motivation to maintain productive cows and education, do not significantly influence motivation to participate in participatory institutions.

The unidirectional relationship among the three previous forms of motivation does not rule out the possibility of institutional development in the early handling of productive female cattle. For the government, the development of institutional models can be continued using socialization to form positive perceptions about the offered institutional models. This can be seen from the very significant relationship between the positive perception of the institutional model (PKLP) and the perception of institutional effectiveness (TKYN) as an indicator of the level of confidence of the $\mathrm{BH}$ towards the institutional model offered, and the existence of a less significant and unidirectional relationship between motivation to participate with institutional perception.

The better the perception of participatory institutional models, the more certain will be given to the $\mathrm{BH}$ about the effectiveness of the program so that it becomes the duty and responsibility of stakeholders to encourage the creation of positive perceptions both through socialization and other informatics activities. The main target of information dissemination is $\mathrm{BH}$ s that have a low risk of releasing productive cows because the estimation results show that the higher the potential for the release of productive cows, the higher the level of confidence. It means that the group that needs to be believed is the $\mathrm{BH}$ group with relatively low income and has a relatively low livestock business role on the household economy.

\section{Conclusions}

The rate of release of productive cows is quite high (19.33\%), driven by factors of business orientation, labor availability, and household characteristics. Mastery over land assets will affect the motivation of $\mathrm{BHs}$ in business development, while the motivation for the release of productive cows is related to the expected scale of business achievements of livestock. In general, the model is acceptable to breeder households. Besides, their level of confidence in the model is closely related to perceptions of the model and the potential for productive cows released by households.

\section{Acknowledgment}

This research was part supported by a grant from Kemenristek-DIKTI through DRPM under the scheme of Stranas 2018 with contract no: $052 / S P 2 H / L T / D R P M / 2018$. We are very thankful for the grant. Sincere appreciations are truly delivered to Prof. Dr. Ir. Edy Kurnianto, MS., M.Agr and Prof. Dr. Ir. Dewi Apri Astuti, MS for reviewing and supporting this manuscript to be published.

\section{References}

AIAT of Central Java and Livestock Office of Central Java. 2005. Study of Cattle Slaughtering in Central Java. Collaboration between Assessment Institute for Agricultural Technology of Central Java and Livestock Office of Central Java.

Chilonda, P. and G. Van Huylenbroeck. 2001. A conceptual framework for the economic analysis of factors influencing decision making of small-scale farmers in animal health management. Rev. Sci. Tech. Off. Int. Epiz. 20: 687-700.

Directorate General of Animal Health and Husbandry. 2011. Technical Guidelines. Incentives and rescue for productive female cattle/buffaloes in 2011. Directorate General of Animal Health and Husbandry of Ministry of Agriculture of Republic of Indonesia, Jakarta.

Hafid, H. and A. Syam. 2001. Observation of the distribution and intensity of slaughtering of productive cows in slaughterhouses in the Municipality of Kendari. Research Report on the Faculty of Agriculture, University of Halualeo, Southeast Sulawesi.

Harmini, R. W. Asmarantaka, and J. Atmakusuma. 2011. The dynamic model of the national beef availability system. Journal of Development Economics (Jurnal Ekonomi Pembangunan) 12: 128-146.

Komarudin, H., Y. Siagian, C. Colfer, Neldysavrino, Yentirizal, Syamsuddin, and D. Irawan. 2008. Collective action to secure property rights for the poor: a case study in Jambi Province, Indonesia. CAPRi (Collective Action and Property Rights) Working Paper No. 90 June 2008.

Livestock Office of Jambi Province. 2007. Save Productive Cows - Prevent Slaughter. Agricultural Extension Worker Edition BPSDMP 10 - 16 October 2007. http://www.disnakjambi@deptan.co.id. Accessed January 12, 2012.

Mahbubi, A. 2014. Madura development program as an island cow perspective management 
of sustainable cattle supply. Agriekonomika: Journal of Socio-Economic and Agricultural Policy (Jurnal Sosial Ekonomi dan Kebijakan Pertanian) 3: 98109.

Management Guidelines of Control of Productive Cow (PBP). 2013. Directive on how to save productive cows. Directorate General of Animal Health and Husbandry of Ministry of Agriculture of Republic of Indonesia, Jakarta.

Novra, A., and Depison. 2009. Alternative solutions for participatory institutional programs for productive cows. Journal of Animal Sciences (Jurnal IImu-ilmu Peternakan) 21: 1-10.

Satriawan, B. and H. Oktavianti. 2012. Efforts to alleviate poverty among farmers use a model of collective action on agricultural institutions. Journal of Development Economics (Jurnal Ekonomi Pembangunan) 13: 96-112.

Soedjana, T. D. 2009. A Bill of animal husbandry, slaughtering productive cows on the criminal. Director-General of Animal Husbandry, Department of Agriculture. https://lifestyle.kompas.com/read/2009/02/ 21/05023570/motong.sapi.betina.productiv e.dipidana. Accessed 02-21-2009.
Soejosopoetro, B. 2011. Study of slaughtering productive cows in Malang Slaughterhouse, Journal of Tropical Livestock (Jurnal Ternak Tropika) 12: 2226.

Suardana, I. W., I. M. Sukada, I. K. Suada, and D. A. Widiasih. 2013. Analysis of the number and age of productive Bali cows slaughtered at the Slaughterhouse of Pesanggaran and Mambal Province of Bali. Journal of Veterinary Science (Jurnal Sain Veteriner) 31: 43-48.

Sudrajad, P., M. Mastur, and Subiharta, 2011. The performance of the development of beef cattle which is facilitated by the rescue program for productive cows in Central Java, Article of Agricultural Technology Assessment Center of Central Java at the National Seminar. Strengthening Agriculture Socio-Economy Towards Welfare. Faculty of Animal Science of UGM, Yogyakarta. December 8, 2011.

Squires, V. R. 2003. Social Behavior in Domestic Livestock: The Basis for Improved Animal Husbandry. Applied Animal Ethology 1: 177-184. 